\title{
Language of instruction: Concerning its choice and social prestige in Burkina Faso
}

\author{
Melanie David-Erb ${ }^{1}$
}

Accepted: 14 February 2021 / Published online: 12 March 2021

(c) The Author(s) 2021

\begin{abstract}
This article explores and discusses one of the main findings of the author's recent dissertation, namely that parents' and pupils' choice of language of instruction in formal schooling depends on its social prestige. The author first reviews the latest research on language in education in sub-Saharan Africa, and asks why indigenous languages are so rarely used in formal schooling in this region, despite political demands for their greater use and ample scientific research showing their positive effects. Burkina Faso exemplifies this seemingly contradictory situation. Indige nous languages and French are complementary in formal and non-formal schooling as well as in areas of informal education; however, a closer look at the areas of application of each language reveals that indigenous languages have lower prestige than French, as well as lower expected and required outcomes. This is one possible explanation for the low usage rates of indigenous languages in formal schooling and reveals the extent to which the choice of language of instruction depends on its social prestige.
\end{abstract}

Keywords language of instruction $\cdot$ sub-Saharan Africa $\cdot$ Burkina Faso $\cdot$ language and social prestige

\section{Résumé}

Langue d'instruction : choix et prestige social, cas du Burkina Faso - Cet article explore et analyse l'une des principales conclusions de la récente thèse de l'auteure, à savoir le fait que le choix de la langue d'enseignement de la part des parents et des élèves pour l'enseignement formel dépend de son prestige social. L'auteure recense les derniers travaux de recherche sur la langue dans l'éducation en Afrique subsaharienne. Puis elle soulève la question de savoir pourquoi les langues autochtones sont si rarement utilisées dans l'enseignement formel de cette région, et ce malgré les revendications politiques pour un usage plus répandu et pour des travaux scientifiques approfondis démontrant leurs effets positifs. Le Burkina Faso illustre cette

Melanie David-Erb

david-erb@em.uni-frankfurt.de

1 Institut für Erziehungswissenschaft, Goethe-Universität, Frankfurt am Main, Germany 
situation apparemment contradictoire. Les langues autochtones et le français sont complémentaires dans l'enseignement formel et non formel ainsi que dans certains domaines de l'éducation informelle. Néanmoins, un examen plus poussé des champs d'application pour chaque langue révèle que les langues autochtones sont moins prestigieuses que le français, et que les acquis escomptés et exigés y sont moins élevés. Ce constat est une explication possible des faibles taux d'utilisation des langues autochtones dans l'enseignement formel, et dévoile dans quelle mesure le choix de la langue d'instruction dépend de son prestige social.

\section{Introduction}

The United Nations Educational, Scientific and Cultural Organization (UNESCO) designated 2019 as the "International Year of Indigenous Languages" (UNESCO 2019). ${ }^{1}$ UNESCO's designation indicates that the persistent discrepancy between the multitude of languages spoken globally and the few that dominate in schools is still a major topic of discussion in various contexts (e.g. the media: see Tiao 2015; education policy: see Ramachandran 2017; culture and development: see Trudell 2016). This issue is of great significance because the extinction of languages is not only a huge cultural loss for mankind, but - even more importantly - the domination of one language by another always reflects the subjugation of a community of speakers. The choice of language of instruction in formal education is one of many factors considered in discussions of language diversity and multilingual societies. In providing equal opportunities for every pupil, politicians responsible for educational policies strive to include every social group and avoid marginalising a linguistic community. On the other hand, it is a major organisational and financial challenge to educate every pupil in their first language. This begs the question: If it were possible to educate every pupil in their first language, would they and their parents even want it?

The debate is complex because of the multitude of actors, and it is ideologically charged because it refers to mechanisms of dominance and oppression at national and global levels. The choice of a language of instruction for formal schooling depends on its social prestige. This article aims to demonstrate that this may be a significant reason why formal educational practices fail to meet either the demands of international organisations such as UNESCO, which advocates for the use of

\footnotetext{
1 The term "indigenous language" requires critical reflection and a clear definition because different scholars interpret it differently. In this article, I refer to languages spoken before the arrival of Europeans, Arabic-speaking traders and missionaries on the African continent as "indigenous languages". This terminology is controversial. On the one hand, sociological analyses by Hannah Bennani and Marion Müller (2018) show how the global category "indigenous" is valuable as a category of difference and contrasts with established ideas of normality (ibid., p. 308). Other scholars consider the term "indigenous" derogatory (e.g. Hountindji 2000; Turnball 1997). Interviews conducted with locals during field research for this work revealed that some interviewees perceive the French term langue indigène as discriminatory. For that reason, this expression was avoided in the interviews. In spite of this, this article uses the term "indigenous language" due to the lack of suitable alternatives in English.
} 
indigenous languages in schools, or the desires of educationists, who have long promoted the benefits of learning in one's mother tongue. The two main sections of this article are based on interviews conducted with representatives of all levels of formal schooling as well as actors in the fields of non-formal education and informal learning. The interviews were conducted in the capital of Burkina Faso, Ouagadougou, in $2013 / 14$. The concluding section shows that social prestige is one of the primary reasons for choosing a language of instruction for formal schooling, often trumping the influence of political commitments and scientific evidence.

\section{Language of instruction as a topic of scientific and political discourse}

UNESCO was a pioneer in the study and promotion of indigenous languages in education. In 1953, UNESCO published a report entitled The Use of Vernacular Languages in Education (UNESCO 1953), which drew the international community's attention to language use in schools. The authors drew a link between the unsatisfactory output of education systems in multilingual, colonised countries with the languages of instruction used. They noted that, on the day of school enrolment, the majority of children did not speak or understand this language sufficiently. The report ends with the claim that children should be given the opportunity to learn, especially in elementary education, though a language they speak outside of school and with which they are familiar.

Since the publication of this document, politicians and scholars have debated intensely the appropriate language of instruction in multilingual societies. In subSaharan Africa, the question of which language(s) to use in instruction has been perhaps the most ubiquitous and long-lasting educational debate since independence, and even dates back to colonial and missionary times (Adick 2013, pp. 139-141). An analysis of the debate reveals six primary factors at work.

Some authors, such as Birgit Brock-Utne (2001) and Lydia Nyati-Saleshando (2011), emphasise the psychological advantages of using indigenous languages at school. They write that pupils feel more secure and accepted when they are allowed to use a language they master instead of being confronted with a language that they speak or understand insufficiently. These researchers believe the use of indigenous languages at school improves pupils' well-being and helps them to develop their own identity and self-esteem.

Others stress the positive influence of the use of indigenous languages on learning outcomes. For example, a study by Jens Naumann et al. (2006) showed that children acquire literacy skills more quickly and successfully if they are taught through the language they speak in their everyday lives. This also applies to learning other languages.

Some authors, such as Ludwig Gerhardt (2004), accentuate the linguistic aspects of the debate. They are concerned with the large number of endangered languages. Samukele Hadebe (2009), for example, examines the status of languages with few remaining speakers and pleads for more researchers to work on orthographies and study their grammar and pronunciation. These researchers hope that using such languages in school may halt their demise. 
Another issue surrounding indigenous languages in education may be described as socio-economic. Here, contributors focus on the relationship between language and power in a society. Scholars such as Birgit Brock-Utne (2001) and Kwesi Kwaa Prah (1995) examine the situation of underprivileged families and draw a connection between their social disadvantages and the languages they speak or in which they were given (or denied) the opportunity to become proficient. Others, like Martha Qorro (2009), explore the linguistic specificity of social elites.

Political factors are another central point of analysis and discussion. Other researchers, such as Christel Adick (1993), adopt a historical perspective, studying the political decisions of colonial administrations that include language policy issues. Wolfgang Mehnert (1974) shows that even though each colonial power had its own ideas for how to deal with language in its colonies, clear dichotomies (e.g. Britain supported indigenous languages, while France suppressed them) are an oversimplification. In addition, political factors influence debates and measures of intervention. For example, international organisations such as UNESCO have heavily influenced national policies on the use of indigenous languages in education.

The final set of arguments in the discussion about indigenous languages in schools is economic. Although it is expensive to incorporate indigenous languages in schools (developing teaching materials, training teachers etc.), as Blasius Chiotah (2011, p. 587) mentions, it makes schooling more efficient over time by shortening primary schooling by one year, which saves staff, material and infrastructure costs (Ilboudo 2010, p. 52).

There seems to be a consensus amongst nearly all stakeholder groups that is largely congruent with UNESCO's 1953 report: The use of languages that children speak outside of school aids their academic performance, especially in the initial years of schooling. Yet the fact remains that indigenous languages are used in formal schooling in very few African countries. How can that be? Why does the scientific and political consensus diverge from the reality of everyday school life? Researchers have formulated different hypotheses to answer this question: Martha Qorro (2009) points to resistance by the parents. Burkinabé linguist Norbert Nikièma (2011) posits a communication deficit that results in popular ignorance about the advantages of indigenous languages in schooling. Alamin Mazrui (1997) identifies global economic and political factors as essential to the dominance of certain languages in education. The following sections present findings from my own research on languages of instruction in Burkina Faso (David-Erb 2020).

\section{Burkina Faso: An example of complementary language use}

Multilingualism is part of everyday life in Burkina Faso, an African country with a great diversity of languages (Gerhardt 2004). The use of languages in different educational contexts is multifaceted and mirrors different historic and current perspectives. While the use of indigenous languages in missionary schools was common in Africa, in schools run by the colonial administration the language of the so-called "mother country" was most often chosen as the language of instruction, especially in areas colonised by francophone powers. Despite marked differences 
Table 1 Complementary language use in Burkina Faso

\begin{tabular}{lll}
\hline & French & Indigenous languages \\
\hline Educational context & formal & non-formal \\
Target group & $\bullet$ children and young adults of school- & illiterate adults \\
& going age & \\
Qualification & graduates & unrecognised certificates \\
Graduates' perspectives & recognised certificate & no qualified vocational \\
& - pubcess to further training & or further training \\
Graduates' social status & $\bullet$ paid work & prospects \\
\hline
\end{tabular}

Source: David-Erb (2020, p. 161) according to descriptions of Nikièma and Kaboré-Paré (2010, p. 193).

between missionary and colonial schools, historical sources show that their practices in relation to language of instruction do not represent a clear dichotomy, neither for French nor for other colonies. ${ }^{2}$ Originating in colonial educational practices, the issue of language of instruction has been hotly debated since independence. The first president of Burkina Faso, Thomas Sankara, a charismatic socialist revolutionary with pan-African and anti-patriarchal views, whom some in the press dubbed "Africa's Che Guevara", initiated an education reform in 1979 of which an essential component was the inclusion as languages of instruction of Mooré, Djoula and Fulfuldé, the three most commonly spoken indigenous languages in Burkina Faso, in the regions of their respective dominance. After the first schools had adopted this reform and the president announced its roll-out across the entire education system, Sankara was killed by his political opponents; his reforms were immediately stopped without further evaluation. The presidency of Sankara's successor, the authoritarian Blaise Compaoré, represented a political U-turn; the education system reverted to the exclusive use of French as language of instruction. Clearly, diverse views and practices have existed throughout the country's history, yet French has been predominant within the formal Burkinabé education system since the colonial era.

Burkina Faso's current education system is informed by its history. The situation in this country is striking in that certain forms of education are assigned to a specific language. While formal schools, with very few exceptions, use French, non-formal establishments often educate pupils in an indigenous language. This separation is also reflected in the target groups and qualifications provided by the different types of schools: children of school age attend formal schools, while non-formal education is targeted to adults with low literacy skills and other disadvantaged groups; pupils at formal schools earn certificates which allow them to progress within the education system, whereas the certificates bestowed by non-formal education do not allow progression to further education institutions or public service employment. Table 1contrasts the contexts in which French and indigenous languages are used.

\footnotetext{
${ }^{2}$ Adick and Mehnert (2001) collected many examples.
} 
The table illustrates the reality of Burkina Faso's policy of a complementary use of languages in education. Different languages are assigned their own social functions and areas of application. The picture is similar if we look at the sector of informal education, i.e. the use of language in media such as radio, television and print, as well as forms of art with high language affinity such as theatre or storytelling. During my field research in Burkina Faso, I used document analysis to explore language practice in those fields and conducted interviews with relevant actors (more details are provided in the methodology section below). My analysis revealed that consumers of art, radio, TV and print in indigenous languages show a particular interest in local issues that affect rural milieu, but seldom in nationally or internationally relevant news. There are several indicators for this, such as the types of newspaper articles that are translated from French into indigenous languages or the topics taken up by indigenous language theatre. Beyond education, indigenous languages are equated with economically and educationally underprivileged social groups. Based on observations of language practice in schools and different forms of public discourse, it becomes clear that indigenous languages are considered less prestigious than French in Burkina Faso. They are primarily associated with rural, educationally disadvantaged milieux. French is associated with the supra-regional, global, economically and socially superior class. The next section shows the extent to which this could be an essential reason for the popular choice of French as the main language of instruction in formal schooling.

\section{The choice of language(s) in education in Burkina Faso from multiple actors' perspectives}

The fieldwork I conducted between December 2013 and March 2014 in Ouagadougou, the capital of Burkina Faso, included interviews with 39 actors in the field of education. I conducted these interviews with the help of a guiding questionnaire with open-ended questions. My study does not claim to be representative. Since almost all of my interviewees lived in the urban environment of the capital, their responses cannot be assumed to reflect the situation in rural areas. The survey involved professionals working in formal education as well as experts in non-formal and informal education. Formal education occurs in schools, leads to state-recognised degrees, and provides access to further formal educational institutions. Non-formal education also takes place under school-like conditions (e.g. fixed space, time and content of learning) as controlled learning, but those "schools" do not award qualifying degrees and are not necessarily recognised by formal institutions. Informal education is defined as learning that occurs outside of educational institutions. This includes, for example, learning based on family or media influences (for more detailed information see Sandhaas 1986 and Evans 1981).

The decision-making process in educational policy passes through different hierarchical stages. As will be discussed in more detail later, several structures are responsible for ensuring that practical requirements are addressed by the ministry and that the ministry's decisions are implemented in schools. The organisation of the actors who implement this concept is finely differentiated. Their functions can 
be analysed because the actors concerned (with the exception of one person representing the Direction Régionale [regional directorate]) were interviewed for this study.

Helmut Fend (2008, p. 17), who views school from a structural functionalist perspective, divides the regulatory instruments of the Burkinabé education system into three levels. First is the micro level, which includes everyone directly affected by school. This includes teaching staff, who act methodically and didactically and perform educational and advisory tasks, and learners, who meet performance standards, are disciplined, and develop individually.

Second is the meso level of de facto school management and school development work. This level is broad and starts with the school administration. Communication between the schools and the higher-level bodies runs through the headmasters. Headmasters report to the Conseillers/Conseillères Pédagogiques [male/female educational advisors]. Every Conseiller/-ère Pédagogique works with a certain number of schools by assisting them in both pedagogical and organisational matters, conducting monthly class visits at each school, holding talks with all school teachers 12 times per year, and leading training courses. He or she provides an important link between the school inspector, to whom they report, and the schools themselves. The Inspecteur or Inspectrice [male/female inspector] directs the pedagogical inspections or school supervision for geographically close schools and coordinates the Conseillers and Conseillères Pédagogiques, who have direct contact with the schools, passing their findings on to the responsible Direction Provinciale [provincial directorate]. One Direction Provinciale is responsible for each of the 45 Burkinabé provinces. This authority coordinates all inspectors in the province. Policy decisions made by the ministry are interpreted and related to the concrete local situations. Each Direction Provinciale belongs to one of 13 Directions Régionales, which coordinate and administer the schools in the 13 regions.

Depending on the type of school, these are under the authority of one of the three legislative ministries of education that act on the macro level. The highest level is responsible for forming education policy, i.e. passing laws, creating courses of study, and defining and regulating certificates and degrees. Schooling is the responsibility of the state. This relates both to the right to set binding targets for educational goals and to the duty to monitor achievement.

Table 2 provides an overview of fields of action and actors in the Burkinabé education system according to Fend (2008, p. 17). The identification of authorities and (groups of) individuals forms the basis for the selection of interview partners.

\section{Methodology}

Interview partners were selected based on their position within this hierarchy. In total, I interviewed 39 people, 26 of whom worked in formal education, i.e. at the micro, meso or macro levels. The ministry official responsible for questions of bilingual education at the Ministère de l'Education de Base et de l'Alpabétisation [Ministry of Basic Education and Literacy] belongs to the macro level. The meso level is represented by the head of a Direction Régionale, an Inspecteur, a Conseillère 
Table 2 Fields of action and actors in education in Burkina Faso (examples)

\begin{tabular}{|c|c|c|c|}
\hline Levels of action & Macro level & Meso level & Micro level \\
\hline Fields of action & $\begin{array}{l}\text { - Culture } \\
\text { - Values and standards }\end{array}$ & $\begin{array}{l}\text { - Educational development } \\
\text { - Quality \& internal evaluation } \\
\text { - School profile }\end{array}$ & $\begin{array}{l}\text { - Class management } \\
\text { - Education } \\
\text { - Instruction } \\
\text { - Consultation } \\
\text { - Methodology \& } \\
\text { didactics } \\
\text { - Development of } \\
\text { teaching }\end{array}$ \\
\hline Actors & $\begin{array}{l}\text { - Social \& political leaders } \\
\text { - Ministries (MASSN, } \\
\text { MEBA, MESSRS)* } \\
\text { - Associations } \\
\text { - Churches } \\
\text { - Economy }\end{array}$ & $\begin{array}{l}\text { - Headmasters } \\
\text { - Conseillers/-ères Pédagogiques } \\
\text { - Inspecteurs/-rices } \\
\text { - Directions Régionales } \\
\text { - Directions Provinciales }\end{array}$ & $\begin{array}{l}\text { - Teachers } \\
\text { - Pupils } \\
\text { - Parents }\end{array}$ \\
\hline
\end{tabular}

Source: David-Erb (2020, p. 158)

Notes: *MASSN stands for Ministère des Affaires Sociales et de la Solidarité Nationale [Ministry of Social Affairs and National Solidarity], MEBA stands for Ministère de l'Education de Base et de l'Alphabétisation [Ministry of Basic Education and Literacy], MESSRS stands for Ministère de l'Education Secondaire et Supérieure et de la Recherche Scientifique [Ministry of Secondary and Higher Education and of Scientific Research]

Pédagogique, and two school principals - one from a bilingual and another from a "classical" school, i.e. a school where French is the only formal language of instruction. The micro level includes two teachers, three parents, four students and three former students from a bilingual school, as well as two teachers, two parents and four students from a classical school. Both schools are located in a socially disadvantaged part of the capital. In the area of non-formal education, interviews were conducted with five employees of different governmental and non-governmental organisations $(\mathrm{NGOs})^{3}$ working with indigenous languages in education. Data on non-formal education were generated from seven interviews with eight persons employed in different areas connected to multilingualism. This group comprises five journalists (print, radio, television), two artists, a publisher and a scientist.

Following the interviews, the recorded data were transcribed and a qualitative content analysis was conducted based on Philipp Mayring's (2010) technique. ${ }^{4}$ Some of the main results support the initial thesis I started out with, which considers social prestige the reason for the choice of language of instruction in formal schooling. These results are presented next.

\footnotetext{
${ }^{3}$ The five organisations were the Association Nationale pour la Traduction de la Bible et 1'Alphabétisation [National association for the translation of the Bible and for literacy] (ANTBA), the Summer Institute of Linguistics (SIL), Solidar Suisse, Tin Tua, and the United Nations Children's Fund (UNICEF).

${ }^{4}$ The interviews were conducted in French, and I carried out the analysis using the French transcriptions. For details on the methods used, see David-Erb (2020, pp. 117f.). The questionnaires can be obtained from the author upon request.
} 


\section{The language question in formal education}

What was particularly striking in the results of the evaluation was how the attitude of the interviewees from the micro level (teachers, pupils, parents) deviated (in some cases, significantly) from the consensus among science and international organisations.

Abdou Moumouni (1975), Lydia Nyati-Saleshando (2011) and Kwesi Kraa Prah (2005) have thoroughly discussed the question of how language use at school influences a child's identity formation. They assume that using a child's first language at school helps the child develop a perception of themselves as competent and valued. These researchers write that excluding the first or family language from schools leads to speakers feeling as though they and their cultural roots were inferior, which can ultimately have a negative impact on learning success. However, the interview data I collected do not confirm that my respondents attached similar relevance to that topic. At the micro level, only one mother and one teacher mentioned this point. While both of their statements primarily emphasise the idea that children should contribute to maintaining endangered cultural practices, they do not refer to the potential benefits that the children might derive from an increased emphasis on their linguistic and cultural roots.

Notably, the Écoles Bilingues [bilingual schools], contrary to their intended purpose (Ilboudo 2010, p. 50), fail to convey to learners that both languages of instruction are equally valuable. Schoolchildren at both the classical and the bilingual schools reported having been punished for using indigenous languages. However, the statements made by the respondents suggest that the quality of the punishments differs; only pupils of the classical school reported receiving physical punishment from the teacher or even from other children.

Another significant deviation concerns the quality of French lessons. Scholars such as Paul Taryam Ilboudo (2010, p. 108) and Norbert Nikièma (2011, p. 206) assume that children who began their education in a language they know well are better able to transfer the knowledge they acquire to other languages than children taught in an unfamiliar language. This means that indigenous instruction ultimately makes learning easier for children when they switch to a second language of instruction later in their formal education. The parents and teachers interviewed for this study as well as the trainers of the teaching staff (Conseillère Pédagogique and Inspecteur) contrasted their experiences with this assumption. They unanimously reported that pupils of bilingual schools have a poorer level of French than graduates of the classical schools, making it difficult for them to switch to a secondary school. For this reason, the respondents felt that shortening the curriculum by one year, which is practised in bilingual schools and considered an achievement because it saves costs for both the state and individual (Ilboudo 2010, p. 52), is in fact a disadvantage. They perceived the loss of this year as depriving the bilingual school pupils of the opportunity to improve their knowledge of French. Some interviewees indirectly criticised the early exit model for its inconsistency. While pupils learn to write in their indigenous language, this ability is not honoured by the education system as a whole, for example in certificates and diplomas. This treatment serves to further marginalise these pupils' first language rather than enhancing its standing in 
society. In the end, some interviewees expressed their fear that because indigenous language instruction ends abruptly after 6th grade and the linguistic content is not taken up again anywhere, the children forget what they have learned.

Parents and teachers from the bilingual schools mentioned a further problem, which is, to my knowledge, not described in any of the literature: parents who are either not literate at all or only in French, i.e. not in the indigenous language used at school, are unable to support their children in the learning process. For several of the parents interviewed, this difficulty is of particular importance, because it makes it more difficult for them to be involved in their children's studies. From the parents' point of view, the decisive argument for bilingual schools is not their languages of instruction but the integration of a practical subject into the curriculum, ${ }^{5}$ something these schools advertise. This policy is less about preserving local traditions, as the theoretical basis for the Écoles Bilingues describes it (Ilboudo 2010, p. 45), and more about giving the pupils an added means of supporting their families' livelihoods. The parents of pupils at some bilingual schools reported disappointment that precisely this policy was not being implemented in their school. It was mainly for the sake of the practical vocational skills that they accepted the use of the indigenous language.

Although in theory indigenous language education is recommended equally for all social classes and family backgrounds, as promoted by researchers such as Hassana Alidou et al. (2006) and Paul Taryam Ilboudo (2010, p. 25), many of the respondents had more specific notions of who should receive it. They expressed the belief that schools which use indigenous languages of instruction tend to be more suitable for girls, children from underprivileged social backgrounds, and children with disabilities and learning difficulties. Graduates of bilingual schools are overwhelmingly assigned to non-academic areas, especially agriculture, for vocational training. Moreover, many respondents stated that, due to the linguistic diversity of urban areas, the Écoles Bilingues are not considered useful for children in larger cities. From the interviewees' perspective, bilingual schools are aimed at the socially disadvantaged based on their expected learning outcomes.

A connection between the choice of language of instruction and a process of decolonisation demanded by intellectuals such as the Kenyan postcolonial thinker Ngũgĩ wa Thiong'o (1986) was not recognised by the parents interviewed. Instead, they expressed a desire for their children to have the best possible access to education and professional success in a globalised world, and the perception that competence in a major international language such as French or English is a key qualification. Decolonialisation did not play a discernible role for them. In their estimation, concrete goals in their individual educational and professional biographies were more important.

\footnotetext{
5 Depending on the region and the craft typically practised there, this might for example be basket weaving, soap-making or even livestock farming.
} 


\section{The language question in non-formal and informal education}

The opinions expressed by the journalists, publishers and artists in their interview responses run contrary to those of parents and teachers on the latter point of decolonisation. Among the 39 interviews I conducted for my study, these respondents were the only ones (outside of the ministry level) who advocated for indigenous language education. In justifying their attitude, they referred to global relationships such as the "decolonialisation of minds" mentioned in the works of Ngũgĩ wa Thiong'o (1986). This view distinguishes highly educated people, who themselves are in the privileged position of mastering multiple languages, including French. This group has a choice that most people in Burkina Faso, especially those with a low level of education, do not have.

Fundamentally, the statements made by the respondents from the fields of nonformal and informal education reflect attitudes already apparent in the interviews with the actors from the formal level. For example, the idea of an educational component in public communication is common to broadcasters like Radio Rurale in Burkina Faso and performative art forms like the Theatre for Development (see also Epskamp 2005), both of which also mainly use indigenous languages. Journalists from the print sector also reported that articles published in indigenous languages were thematically rather homogenous and geared towards the supposed interests of a rural population with a low level of formal education. The fact that the public use of these languages is clearly aimed at raising awareness of them and at educating the rural population means that these languages - in Pierre Bourdieu's (1985) terms - have an extremely low market value. Globally relevant news or reports are rarely published in indigenous languages, if at all; instead, featured topics are of the kind which deal specifically with farmers' living environment. This consolidates the image of these languages as belonging to the economically poor. Those who reject such a classification for their own children will prefer a monolingual francophone school.

\section{Conclusion: social prestige as the main reason for choice of language of instruction}

The Écoles Bilingues in Burkina Faso, which were designed and are financed by the Swiss NGO Solidar Suisse, are one example of a global trend (see Peters et al. 2012, p. 6) in which NGOs proactively intervene in state matters as independent political actors. In this case, Solidar Suisse acts as a mediator between Burkinabé society and the guidelines proposed by international agencies and the research community. The organisation provides (knowledge) resources and argues that it represents national interests.

The decisions of individual actors at the micro level, however, prevent structural alignment with the norm, which is primarily required for pedagogical reasons. Instead, they lead to an alignment with other global trends, namely towards the dominance of a few "world languages". Here, people are guided by economic values, the 
adoption of which they hope will result in better chances on the job market and ultimately better earning opportunities. Accordingly, two competing standard systems meet; the global discourse of science and international organisations based on pedagogical maxims, and the learners (or their parents) who orient themselves according to the economic utility of education.

Likewise, a look at the government's pronouncements and its legislative changes regarding language use in schools shows that the government of Burkina Faso maintains a façade of openness to the proposals of international organisations, but gives priority to other - primarily political and economic - arguments in implementation. John Meyer et al. (1992) describe a process of structural adjustment which cannot influence the level of everyday practice solely through normative discourse led by international actors. The aspect of desiring an economic advantage for oneself, on the other hand, plays a decisive role and undermines this concept. The belief that mastering a particular language will help fulfil this hope seems to be largely linked to the social prestige attributed to that language. In other words, the parents' and pupils' attitude to a language is based on the prestige that they perceive is attached to it. For this reason, people will avoid a school in which a low-prestige language - one that is deemed unable to fulfil those hopes - is used as the language of instruction. Therefore, the model cannot expand, although it is favoured by the normative top-down discourse led by international actors and policymakers. In this case, the most powerful decision-makers are those who actually avail of the institution. The discourse that they lead is oriented more towards economic than pedagogical considerations, and more specifically towards the economic utility of education.

Funding Open Access funding enabled and organized by Projekt DEAL.

Open Access This article is licensed under a Creative Commons Attribution 4.0 International License, which permits use, sharing, adaptation, distribution and reproduction in any medium or format, as long as you give appropriate credit to the original author(s) and the source, provide a link to the Creative Commons licence, and indicate if changes were made. The images or other third party material in this article are included in the article's Creative Commons licence, unless indicated otherwise in a credit line to the material. If material is not included in the article's Creative Commons licence and your intended use is not permitted by statutory regulation or exceeds the permitted use, you will need to obtain permission directly from the copyright holder. To view a copy of this licence, visit http://creativecommons.org/licen ses/by/4.0/.

\section{References}

Adick, C. (1993). Muttersprachliche und fremdsprachliche Bildung im Missions- und Kolonialschulwesen [Mother tongue and foreign language education in missionary and colonial education]. Bildung und Erziehung, 46(3), 283-298. https://doi.org/10.7788/bue.1993.46.3.283.

Adick, C. (2013). Bildung in Subsahara-Afrika [Education in sub-Saharan Africa]. In C. Adick (Ed.), Bildungsentwicklungen und Schulsysteme in Afrika, Asien, Lateinamerika und der Karibik [Educational developments and school systems in Africa, Asia, Latin America and the Caribbean] (pp. 125-146). Historisch-vergleichende Sozialisations- und Bildungsforschung, vol. 11. Münster: Waxmann. 
Adick, C., \& Mehnert, W. (2001). Deutsche Missions- und Kolonialpädagogik in Dokumenten: Eine kommentierte Quellensammlung aus den Afrikabeständen deutschsprachiger Archive 1884-1914 [German missionary and colonial education in documents: An annotated source collection from the African holdings of German-language archives 1884-1914]. Frankfurt am Main: IKO-Verlag für interkulturelle Kommunikation.

Alidou, H., Boly, A., Brock-Utne, B., Diallo, Y.S., Heugh, K., \& Wolff, E. (2006). Optimizing learning and education in Africa: The language factor. A stock-taking research on mother tongue and bilingual education in sub-Saharan Africa. Paris: Association for the Development of Education in Africa (ADEA). Retrieved 17 August 2020 from http://www.adeanet.org/adea/downloadcenter/ Ouga/B3_1_MTBLE_en.pdf.

Bennani, H., \& Müller, M. (2018). "Making up people” globally: Die Institutionalisierung globaler Personenkategorien am Beispiel indigener Völker und Menschen mit Behinderungen ["Making up people" globally: The institutionalisation of global categories of persons using the example of indigenous peoples and people with disabilities]. Zeitschrift für Soziologie, 47(5), 306-331. https://doi. org/10.1515/zfsoz-2018-0120.

Bourdieu, P. (1985). The market of symbolic goods. Poetics, 14(1-2), 13-44. https://doi.org/https://doi. org/10.1016/0304-422X(85)90003-8.

Brock-Utne, B. (2001). Education for all - in whose language? Oxford Review of Education, 27 (1), 115134. https://doi.org/10.1080/03054980125577.

Chiotah, B. (2011). Sustaining mother tongue medium education: An inter-community self-help framework in Cameroon. International Review of Education, 57(5-6), 583-597. https://doi.org/10.1007/ s11159-011-9247-3.

David-Erb, M. (2020): Indigene Sprachen in der Bildung: Der Eigensinn der Bildungspraxis gegenüber Bildungspolitik und Forschung am Beispiel von Burkina Faso [Indigenous languages in education: The stubbornness of educational practice vis-à-vis educational policy and research. The example of Burkina Faso]. Research in Socialisation and Education series, vol. 18. Münster: Waxmann.

Epskamp, K.P. (2005). Theatre for development and the empowerment of development support communication in Africa. In K. Ansu-Kyeremen (Ed.), Indigenous communication in Africa: Concepts, applications and prospects (pp. 85-102). Accra: Ghana University Press.

Evans, D.R. (1981). The planning of non-formal education. Paris: UNESCO Institute for Educational Planning. Retrieved 17 August 2020 from https://unesdoc.unesco.org/ark:/48223/pf0000076764.

Fend, H. (2008). Schule gestalten: Systemsteuerung, Schulentwicklung, Unterrichtsqualität [Designing school: System control, school development, teaching quality]. Wiesbaden: VS Verlag für Sozialwissenschaften. https://doi.org/10.1007/978-3-531-90867-0.

Gerhardt, L. (2004). Sprachen [Languages]. In R. Hofmeier \& A. Mehler (Eds), Kleines Afrika-Lexikon [Small encyclopaedia of Africa] (pp. 271-272). Munich: C.H. Beck Verlag.

Hadebe, S. (2009). From standardisation to harmonisation: A survey of the sociolonguistic and political conditions for the creation of Nguni in Southern Africa. In B. Brock-Utne \& I. Skattum (Eds), Languages and education in Africa: A comparative and transdisciplinary analysis (pp. 275-285). Oxford: Symposium Books.

Hountindji, P. (Ed.). (2000). Endogenous knowledge: Research trials. Dakar: Council for the Development of Social Science Research in Africa (CODESRIA).

Ilboudo, P.T. (2010). Bilingual education in Burkina Faso: An alternative approach for quality basic education. Case Studies series No 11. Tunis: Association for the Development of Education in Africa (ADEA).

Mayring, P. (2010). Qualitative Inhaltsanalyse: Grundlagen und Techniken [Qualitative content analysis: Basics and techniques]. Weinheim: Beltz.

Mazrui, A. (1997). The World Bank, the language question and the future of African education. Race and Class. A Journal for Black and Third World Liberation, 38(3), 25-49. https://doi.org/10.1177/03063 9689703800303.

Mehnert, W. (1974). Zur Sprachenfrage in der Kolonialpolitik des deutschen Imperialismus [On the language question in the colonial policy of German imperialism]. Vergleichende Pädadogik, 10(1), 52-60.

Meyer, J.W., Kamens, D.H. \& Benavot, A. (1992). School knowledge for the masses: World models and national primary curricular categories in the twentieth century. Washington DC/London: The Falmer Press.

Moumouni, A. (1975). The return to national languages and cultures. Prospects, 5(1), 63-70. https://doi. org/10.1007/BF02220209. 
Naumann, J., Jansen R. \& Franke, N. (2006). Research findings on textbooks and education for all. In C. Braslavsky (Ed.), Textbooks and quality learning for all: Some lessons learned from international experiences (pp. 93-194). Paris: UNESCO. Retrieved 17 August 2020 from https://unesdoc.unesco. org/ark:/48223/pf0000150167.

Nikièma, N. (2011). A first-language-first multilingual model to meet the quality imperative in formal basic education in three "francophone" West African countries. In International Review of Education, 57(5-6), 599-616. https://doi.org/10.1007/s11159-011-9253-5.

Nikièma, N., \& Kaboré-Paré, A. (2010). Burkina Faso. In Organisation internationale de la Francophonie (OIF), Agence française de développement (AFD) \& Ministères des Affaires étrangères et européennes (MAEE) (Eds), Les langues de scolarisation en Afrique francophone: Enjeux et repères pour l'action. Études-pays. [Languages of instruction in francophone Africa: Challenges and benchmarks for action. Case studies] (pp. 189-308). Paris: Agence Universitaire de la Francophonie (AUF). Retrieved 17 August 2020 from https://bibliotheque.auf.org/doc_num.php?explnum_id=825.

Ngũgĩ wa Thiong'o (1986). Decolonising the mind: The politics of language in African literature. London: James Currey.

Nyati-Saleshando, L. (2011). An advocacy project for multilingual education: The case of the Shiyeyi language in Botswana. In International Review of Education, 57(5-6), 567-582. https://doi.org/10. 1007/s11159-011-9254-4.

Peters, D., Freistein, K., \& Leininger, J. (2012). Theoretische Grundlagen zur Analyse internationaler Organisationen [Theoretical foundations for the analysis of international organisations]. In K. Freistein \& J. Leininger (Eds), Handbuch internationale Organisationen: Theoretische Grundlagen und Akteure [Handbook of international organisations: Theoretical foundations and actors] (pp. 3-27). Munich: Oldenbourg-Verlag.

Prah, K.K. (1995). African languages for the mass education of Africans. Cape Town: Centre for Advanced Studies of African Society (CASAS).

Prah, K.K. (2005). Language of instruction for education, development and African emancipation. In B. Brock-Utne \& R.K. Hopson (Eds), Languages of instruction for African emancipation: Focus on postcolonial context and considerations (pp. 23-49). Cape Town: Mkuki Na Nyota.

Qorro, M.S. (2009). Parents' and policy makers' insistence on foreign languages as media of instruction in Africa: Restricting access to quality education - for whose benefit? In B. Brock-Utne \& I. Skattum (Eds), Languages and education in Africa: A comparative and transdisciplinary analysis (pp. 57-82). Oxford: Symposium Books.

Ramachandran, R. (2017). Medium of Instruction policies and efficacy educational systems in sub-Saharan Africa. Background Paper prepared for the 2017/8 Global Education Monitoring Report. Paris: UNESCO. Retrieved 17 August 2020 from https://unesdoc.unesco.org/ark:/48223/pf0000259578.

Sandhaas, B. (1986). Bildungsformen [Forms of education]. In Haller, H.-D \& Meyer, H. (Eds), Ziele und Inhalte der Erziehung und des Unterrichts [Aims and contents of education and teaching] (pp. 399406). Enzyklopädie Erziehungswissenschaft, vol. 3. Stuttgart: Klett-Cotta.

Tiao, B.L.A. (2015). Régulation des medias d'Afrique Francophone : cas du Burkina Faso [Media regulation in francophone Africa: the case of Burkina Faso]. Sciences de 1'Information et de la Communication. Bordeaux: Université Michel Montaigne. Retrieved 17 August 2020 from https://tel.archi ves-ouvertes.fr/tel-01239847/document.

Trudell, B. (2016). The impact of language policy and practice on children's learning: Evidence from Eastern and Southern Africa. Nairobi: UNICEF. Retrieved 17 August 2020 from https://www. unicef.org/esaro/UNICEF(2016)LanguageandLearning-FullReport(SingleView).pdf.

Turnball, D. (1997). Masons, tricksters and cartographers: Comparative studies in the sociology of scientific and indigenous knowledge. London: Routledge.

UNESCO (United Nations Scientific, Educational and Cultural Organization) (1953). The use of vernacular languages in education. Monographs in Fundamental Education series, vol. 8. Paris. UNESCO. Retrieved 22 February 2019 from https://unesdoc.unesco.org/ark:/48223/pf0000002897.

UNESCO (2019). 2019: International year of Indigenous languages [dedicated website]. Retrieved 22 February 2019 from https://en.iyil2019.org/.

Publisher's Note Springer Nature remains neutral with regard to jurisdictional claims in published maps and institutional affiliations. 
Melanie David-Erb PhD, worked as a lecturer at the University of Ouagadougou, Burkina Faso from 2011 to 2014 supported by the German Academic Exchange Service (DAAD). This inspired her PhD thesis on language use in educational contexts in Burkina Faso, which she wrote while employed at the University of Münster. In November 2019, she defended her thesis, entitled Indigene Sprachen in der Bildung: Der Eigensinn der Bildungspraxis gegenüber Bildungspolitik und Forschung am Beispiel von Burkina Faso [Indigenous languages in education: The stubbornness of educational practice vis-à-vis educational policy and research. The example of Burkina Faso], which has since been published (Waxmann 2020). Since 1 April 2020, she has been a post-doctoral fellow in educational science at Goethe University in Frankfurt am Main, Germany. 